\title{
ANALISIS PENYUSUNAN ANGGARAN DAN REALISASI BELANJA DAERAH PADA BADAN PERENCANAAN PENELITIAN DAN PENGEMBANGAN DAERAH KOTA MANADO
}

\author{
Fanda Jessika Mentang $^{1}$, Harijanto Sabijono ${ }^{2}$, Sonny Pangerapan $^{3}$ \\ 1, 2, 3 Jurusan Akuntansi, Fakultas Ekonomi dan Bisnis, Universitas Sam Ratulangi, Jl. Kampus Bahu, Manado, \\ 95115, Indonesia \\ E-mail: mentangfanda@gmail.com
}

\begin{abstract}
Expenditure is one component that is of public concern in the Budget Realization Report. This study aims to: (1) find out the procedures for preparing the budget for the Manado City Regional Research and Development Planning Board; (2) find out the consideration factors in preparing the budget for the Manado City Regional Research and Development Planning Board; and (3) analyze the difference between the realization with a budget for the Manado City Regional Research and Development Planning Agency. The analytical method used in this thesis research is a descriptive method in which all data relating to the budget are collected to be analyzed and then drawn a conclusion. The results obtained show that the procedures for preparing the budget and the factors considered in preparing the budget are good, even in the implementation of the preparation are in accordance with the guideliness and the results of the analysis of variance (deviations) from the 2016-2018 fiscal year are still profitable because the realization is still lower than budgeted.
\end{abstract}

Keywords: budgeting; expenditure realization; expenditure variance

\section{PENDAHULUAN}

Peraturan Menteri Dalam Negeri Nomor 21 Tahun 2011 menjelaskan bahwa pemerintah pusat memberikan kewenangan kepada pemerintah daerah untuk mengurus anggaran daerah tersebut dengan meminimalkan campur tangan pemerintah pusat dan melibatkan dua pihak yaitu eksekutif dan legislatif. Pemerintah daerah dalam upaya melaksanakan kegiatan atau program pelayanan kepada masyarakat tidak dapat melaksanakannya tanpa adanya anggaran. Anggaran merupakan alat untuk menghubungkan antara proses perencanaan dan proses pengendalian. Sebagai alat pengendalian, anggaran memberikan rencana detail mengenai pengeluaran pemerintah agar setiap perbelanjaan yang dilakukan oleh pemerintah dapat dipertanggungjawabkan kepada publik.

Pengalaman yang terjadi saat ini menunjukkan bahwa anggaran daerah masih harus disempurnakan. Menurut Puranta dan Yunita (2010:10), banyak sekali ditemukan keluhan masyarakat yang berkaitan dengan pengalokasian anggaran yang tidak sesuai dengan kebutuhan dan skala prioritas serta kurang mencerminkan aspek ekonomis, efisiensi dan efektivitas. Dalam Peraturan Pemerintah Nomor 71 Tahun 2010 menjelaskan tujuan adanya laporan realisasi anggaran adalah menetapkan dasar-dasar penyajian laporan realisasi anggaran untuk pemerintah dalam rangka untuk memenuhi tujuan akuntabilitas sebagaimana ditetapkan oleh peraturan perundang-undangan, serta memberikan informasi realisasi dan anggaran entitas pelaporan.

Nuru et al. (2013) menemukan bahwa transparansi merupakan prinsip keterbukaan yang memungkinkan masyarakat untuk mengetahui dan mendapatkan akses informasi seluasluasnya tentang keuangan daerah. Menganalisis anggaran dan realisasi belanja daerah seringkali terdapat selisih di mana terdapat ketidaksesuian dalam penggunaan dana yang sudah dianggarkan dan yang terealisasi oleh pemerintah, sebagaimana dana tidak digunakan 
secara efektif dan efisien, karena kurangnya pengendalian dan pengawasan dari pemerintah untuk setiap program dan kegiatan. Selisih anggaran yang terdapat dalam laporan realisasi seringkali berdampak pada kinerja pemerintah daerah. Perbedaan atau selisih yang terdapat antara anggaran dan realisasi anggaran disebut varians.

Badan Perencanaan Penelitian dan Pengembangan Daerah Kota Manado dalam melaksanakan tugas-tugas dalam bidang pemerintahan harus merencanakan, melaksanakan dan mempertanggungjawabkan setiap program/kegiatan dalam rangka melaksanakan tugas bahkan fungsinya untuk mendukung terciptanya pemerintahan yang baik dan bersih, untuk itu agar anggaran yang ditetapkan untuk membiayai semua kebutuhan program yang dijalankan serta realisasi dapat sesuai dengan anggaran yang ditetapkan.

\section{TINJAUAN PUSTAKA}

Menurut Sujarweni (2015:1), akuntansi adalah suatu aktivitas jasa yang terdiri dari mencatat, mengklasifikasikan, dan melaporkan kejadian atau transaksi ekonomi yang akhirnya akan menghasilkan suatu informasi keuangan yang akan dibutuhkan oleh pihakpihak tertentu untuk pengambilan keputusan. Giri (2017:3) menyatakan bahwa sebagai suatu proses, akuntansi merupakan proses pengidentifikasian, pengukuran, pencatatan, pengklasifikasian, penguraian, peringkasan, dan pengkomunikasian informasi keuangan tentang aktivitas suatu entitas bisnis kepada pihak-pihak yang berkepentingan.

Menurut Mahsun (2013:5), sektor publik seringkali dipahami sebagai segala sesuatu yang berhubungan dengan kepentingan umum dan penyediaan barang atau jasa kepada publik yang dibayar melalui pajak atau pendapatan negara lain yang diatur dengan hukum. Akuntansi sektor publik secara umum bertujuan untuk menyajikan informasi keuangan terhadap beberapa alasan mengapa perlu dibuat laporan keuangan. Dilihat dari sisi internal pemerintahan, laporan keuangan merupakan alat pengendalian dan evaluasi kinerja manajerial dan organisasi.

Peraturan Pemerintah Nomor 58 Tahun 2005 tentang pengelolaan keuangan daerah, menjelaskan bahwa keuangan daerah adalah semua hak dan kewajiban dalam rangka penyelenggaraan pemerintah daerah yang dapat dinilai dengan hak dan kewajiban daerah tersebut. Pengelolaan keuangan daerah adalah keseluruhan kegiatan yang meliputi perencanaan, pelaksanaan, penatausahaan, pelaporan, pertanggungjawaban, dan pengawasan keuangan daerah. Pengelolaan keuangan daerah sebagaimana dimaksud, merupakan subsistem dari sistem pengelolaan keuangan negara dan merupakan elemen pokok dalam penyelenggaraan pemerintahan daerah.

Sujarweni (2015:28) menyatakan bahwa anggaran sektor publik adalah pertanggungjawaban dari pemegang manajemen organisasi untuk memberikan informasi tentang segala aktivitas dan kegiatan organisasi kepada pihak pemilik organisasi atas pengelolaan dana publik dan pelaksanaan berupa rencana-rencana program yang dibiayai dengan uang publik. Isi dari anggaran adalah rencana kegiatan dalam suatu periode yang direpresentasikan dalam bentuk rencana pendapatan dan belanja dalam satuan moneter. Selain itu anggaran adalah alat ekonomi terpenting yang dimiliki pemerintah untuk mengarahkan perkembangan sosial dan ekonomi, menjamin kesinambungan, dan meningkatkan kualitas hidup masyarakat. Mardiasmo (2018:63) mengemukakan beberapa fungsi anggaran yaitu: (a) anggaran sebagai alat perencanaan; (b) anggaran sebagai alat pengendalian; (c) anggaran sebagai alat kebijakan fiskal; (d) anggaran sebagai alat politik; (e) anggaran sebagai alat koordinasi dan komunikasi; (f) anggaran sebagai alat penilaian kinerja; (g) anggaran sebagai alat motivasi; dan (h) anggaran sebagai alat menciptakan ruang publik.

Menurut Sujarweni (2015:32), penyusunan anggaran dan pelaksanaan anggaran dilakukan dalam satu periode dan merupakan satu rangkaian proses yang saling berkaitan. Adapun proses penyusunan anggaran mempunyai 4 tujuan, yaitu: (1) untuk memberikan 
bantuan kepada sektor publik agar dapat mencapai tujuan dan meningkatkan koordinasi antar bagian dalam lingkungan; (2) untuk membantu menciptakan efisiensi, efektifitas dan asas keadilan dalam menyediakan barang dan jasa publik melalui proses prioritas; (3) memungkinkan pemerintah untuk memenuhi prioritas belanja; dan (4) meningkatkan transparansi dan pertanggungjawaban manajemen organisasi sektor publik.

Siregar (2017:117) mengemukakan bahwa laporan realisasi anggaran merupakan laporan yang menyajikan ikhtisar sumber, alokasi dan pemakaian sumber daya ekonomi yang dikelola oleh pemerintah pusat ataupun pemerintah daerah. Laporan realisasi anggaran merupakan laporan yang menyajikan perbandingan selisih antara anggaran dan realisasinya. Menurut Peraturan Pemerintah Nomor 12 Tahun 2019, belanja daerah adalah semua kewajiban pemerintah daerah yang diakui sebagai pengurangan nilai kekayaan bersih dalam periode tahun anggaran berkenaan. Mahmudi (2016:154) menyatakan bahwa hal yang paling penting untuk menganalisis belanja daerah dimana untuk mengevaluasi apakah pemerintah daerah telah melakukan anggaran belanja daerah secara ekonomis, efisien dan efektif serta sejauh mana pemerintah daerah telah melakukan efisiensi anggaran, menghindari pengeluaran yang tidak perlu dan pengeluaran yang tidak tepat sasaran. Analisis varians merupakan analisis terhadap perbedaan atau selisih antara realisasi belanja dengan yang disajikan atau dinyatakan dengan rumus:

Varians Belanja Daerah = Realisasi Belanja - Anggaran Belanja

Menghitung persentase tingkat ketercapaian belanja:

$$
\text { Persentase Tingkat Ketercapaian }=\frac{\text { Realisasi Belanja }}{\text { Anggaran Belanja }} \times 100 \%
$$

Liando dan Elim (2016) menunjukkan bahwa kinerja belanja yang sudah baik pada Dinas Pendapatan Pengelolaan Keuangan dan Aset Daerah di Kabupaten Kepulauan Sangihe. Kainde (2013) dalam menganalisis varians dan pertumbuhan belanja daerah pada Dinas Pengelola Keuangan dan Barang Milik Pemerintah Kota Bitung menunjukan bahwa dalam pelaksanaan anggaran masih kurang efektif terdapat selisih negatif antara realisasi anggaran belanja dengan anggaran yang dianggarkan, serta pertumbuhan belanja memiliki kenaikan. Tantri dan Irmawati (2018) dalam menganalisis kinerja anggaran belanja pada Dinas Kebudayaan Daerah Istimewa Yogyakarta menunjukkan bahwa dari tahun 2012-2016 secara keseluruhan kinerja belanja sudah baik.

\section{METODE PENELITIAN}

Penelitian yang digunakan adalah deskriptif kualitatif yaitu mendeskripsikan data apa adanya dan menjelaskan data atau kejadian dalam penyusunan anggaran dan selisih realisasi dan anggaran belanja daerah dengan kalimat penjelasan secara kualitatif. Objek penelitian ini dilaksanakan pada Badan Perencanaan Penelitian dan Pengembangan Daerah Kota Manado dari bulan Juli sampai Oktober tahun 2019. Jenis data yang digunakan yaitu data kualitatif dan data kuantitatif. Data kualitatif berupa hasil wawancara dan gambaran umum Badan Perencanaan Penelitian dan Pengembangan Daerah Kota Manado dan data kuantitatif yang digunakan yaitu, laporan realisasi anggaran tahun 2016-2018.

Sumber data yang digunakan di penelitian ini adalah data primer yang diperoleh langsung dari Badan Perencanaan Penelitian dan Pengembangan Daerah Kota Manado. Metode pengumpulan data yang dilakukan adalah dokumentasi dan wawancara. Penelitian ini menguraikan hasil analisis dari belanja daerah dengan metode analisis dimulai dengan perhitungan varians belanja. Berdasarkan laporan realisasi anggaran besarnya varians anggaran belanja dan realisasinya yang biasa dinyatakan dalam bentuk nilai nominalnya atau persentasenya. Proses analisis pada penelitian ini adalah: 
1. Mengumpulkan data yang berkaitan dengan penelitian ini yaitu wawancara dan laporan realisasi anggaran belanja badan perencanaan dan pengembangan daerah kota Manado tahun anggaran 2016-2018.

2. Mempelajari data yang diperoleh.

3. Menguraikan data yang diperoleh seperti prosedur dan faktor-faktor yang menjadi pertimbangan dalam penyusunan anggaran, kemudian menganalisis selisih antara anggaran belanja dengan realisasinya menggunakan alat analisis yaitu varians belanja daerah di mana akan mencari selisihnya kemudian menghitung persentase tingkat ketercapaiannya.

4. Memberikan kesimpulan dan saran.

\section{HASIL PENELITIAN DAN PEMBAHASAN}

\subsection{Hasil penelitian}

Berdasarkan hasil wawancara dengan Ibu Maria Runtuwene selaku Kepala Sub

Bagian Keuangan, maka prosedur penyusunan anggaran belanja adalah:

1. Menyusun Rencana Kerja (Renja). Dalam proses menyusun Rencana Kerja (Renja) semua kepala bidang yang ada pada Badan Perencanaan Penelitian dan Pengembangan Daerah Kota Manado hadir untuk rapat koordinasi penentuan program atau kegiatan yang akan dilaksanakan.

2. Walikota Manado menyusun Rancangan Kebijakan Umum Anggaran (KUA) dan rancangan Prioritas Plafon Anggaran Sementara (PPAS) berdasarkan Rencana Kerja Pemerintah Daerah (RKPD) dan Pedoman Penyusunan Anggaran Pendapatan dan Belanja Daerah (APBD) yang ditetapkan Menteri Dalam Negeri setiap tahunnya.

3. Rancangan Kebijakan Umum Anggaran (KUA) dan rancangan Prioritas Plafon Anggaran Sementara (PPAS) disampaikan Kepala Daerah kepada Dewan Perwakilan Rakyat Daerah (DPRD) untuk dibahas dalam pembicaraan pendahuluan rancangan anggaran pendapatan dan belanja daerah tahun anggaran berikutnya. Pembahasan dilakukan oleh Tim Anggaran Pemerintah Daerah (TAPD) bersama Badan Anggaran Dewan Perwakilan Rakyat Daerah (DPRD).

4. Rancangan Kebijakan Umum Anggaran (KUA) dan rancangan Prioritas Plafon Anggaran Sementara (PPAS) yang telah dibahas selanjutnya disepakati menjadi Kebijakan Umum Anggaran (KUA) dan Prioritas Plafon Anggaran Sementara (PPAS). Kebijakan Umum Anggaran (KUA) merupakan dokumen yang memuat kebijakan pendapatan, belanja, dan pembiayaan untuk periode 1 (satu) tahun. Prioritas Plafon Anggaran Sementara (PPAS) merupakan prioritas atau patokan batas maksimal anggaran yang diberikan kepada Satuan Kerja Perangkat Daerah (SKPD) dalam hal ini pada Badan Perencanaan Penelitian dan Pengembangan Daerah Kota Manado sebagai acuan dalam penyusunan Rencana Kerja Anggaran (RKA) setelah disepakati oleh Dewan Perwakilan Rakyat Daerah (DPRD), kemudian Kebijakan Umum Anggaran (KUA) dan Prioritas Plafon Anggaran Sementara (PPAS) ini dituangkan dalam nota kesepakatan dan ditandatangani oleh Walikota dan Dewan Perwakilan Rakyat Daerah Kota Manado.

5. Berdasarkan nota kesepakatan, selanjutnya Tim Anggaran Pemerintah Daerah (TAPD) menyiapkan rancangan surat edaran kepala daerah tentang pedoman penyusunan Rencana Kerja Anggaran (RKA) sebagai acuan Kepala Satuan Kerja Perangkat Daerah (SKPD) dalam hal ini Kepala Badan Perencanaan Penelitian dan Pengembangan Daerah Kota Manado dalam menyusun Rencana Kerja Anggaran (RKA).

6. Rencana Kerja Anggaran (RKA) yang telah disusun disampaikan kepada Pejabat Pengelola Keuangan Daerah (PPKD) untuk dibahas lebih lanjut oleh Tim Anggaran Pemerintah Daerah (TAPD) sebagai bahan penyusunan Rancangan Peraturan Daerah tentang Anggaran Pendapatan dan Belanja Daerah (Raperda APBD). 
7. Walikota Manado menyampaikan Rancangan Peraturan Daerah tentang Anggaran Pendapatan dan Belanja Daerah (Raperda APBD) beserta lampirannya kepada Dewan Perwakilan Rakyat Daerah (DPRD). Pembahasan Rancangan Peraturan Daerah tentang Anggaran Pendapatan dan Belanja Daerah (Raperda APBD) ditekankan pada kesesuaian rancangan Anggaran Pendapatan dan Belanja Daerah (APBD) dengan Kebijakan Umum Anggaran (KUA) dan Prioritas Plafon Anggaran Sementara (PPAS). Hasil pembahasan tersebut dituangkan dalam dokumen persetujuan bersama antara Walikota dan Dewan Perwakilan Rakyat Daerah Kota Manado.

8. Rancangan Peraturan Daerah (Raperda) tentang Anggaran Pendapatan dan Belanja Daerah (APBD) dan rancangan peraturan walikota tentang penjabaran Anggaran Pendapatan dan Belanja Daerah (APBD) yang telah dievaluasi kemudian ditetapkan oleh Walikota Manado.

9. Kepala Pejabat Pengelola Keuangan Daerah (PPKD) memberitahukan kepada Kepala Badan Perencanaan Penelitian dan Pengembangan Daerah Kota Manado untuk menyusun Dokumen Pelaksanaan Anggaran (DPA-SKPD).

Faktor-faktor pertimbangan dalam penyusunan anggaran belanja Badan Perencanaan Penelitian dan Pengembangan Daerah Kota Manado:

1. Kegiatan harus ada luaran yang jelas. Hal ini akan memudahkan bagi Badan Perencanaan Penelitian dan Pengembangan Daerah Kota Manado untuk dapat melihat dan menentukan rencana kegiatan dan luaran yang akan dihasilkan seperti apa.

2. Efisiensi (kesesuaian harga). Melihat dari rencana program dan kegiatan yang dilaksanakan hal yang terpenting selanjutnya adalah efisiensi penggunaan anggaran atau dana, selain luarannya harus jelas, tetapi juga masukkan atau dana yang dihasilkan harus jelas dan tidak akan terjadi pemborosan.

3. Anggaran belanja tahun sebelumnya. Anggaran tahun sebelumnya sangat berpengaruh dalam penyusunan anggaran, karena anggaran belanja tahun sebelumnya akan menjadi bahan evaluasi dan penilaian kinerja untuk anggaran tahun berikutnya.

Analisis varians belanja antara anggaran dengan realisasi yaitu untuk dapat menilai dan mengevaluasi kinerja anggaran di mana untuk dapat mengetahui seberapa besar selisih yang terjadi antara anggaran dengan realisasi. Tabel 1 menyajikan hasil analisis guna melihat sejauh mana efisiensi dan efektivitas dalam penyusunan anggaran belanja pada Badan Perencanaan Penelitian dan Pengembangan Daerah Kota Manado.

Tabel 1. Analisis varians belanja

\begin{tabular}{ccccc}
\hline Tahun & $\begin{array}{c}\text { Anggaran } \\
\text { (Rp.) }\end{array}$ & $\begin{array}{c}\text { Realisasi } \\
\text { (Rp.) }\end{array}$ & $\begin{array}{c}\text { Selisih } \\
\text { (Varians) }\end{array}$ & $\begin{array}{c}\text { Tingkat } \\
\text { Ketercapaian }\end{array}$ \\
\hline (a) & $(\mathbf{b})$ & $(\mathbf{c})$ & $(\mathbf{d})=(\mathbf{c})-(\mathbf{b})$ & $(\mathbf{e})=(\mathbf{c}: \mathbf{b}) \mathbf{x}$ 100\% \\
\hline 2016 & $15.426 .610 .424,00$ & $13.388 .359 .703,00$ & $2.038 .250 .721,00$ & $86,79 \%$ \\
2017 & $15.119 .951 .150,00$ & $12.719 .002 .510,00$ & $2.400 .948 .640,00$ & $84,12 \%$ \\
2018 & $19.303 .021 .850,00$ & $17.542 .554 .895,00$ & $1.760 .466 .955,00$ & $90,88 \%$ \\
\hline
\end{tabular}

Sumber: Badan Perencanaan Penelitian dan Pengembangan Daerah Kota Manado (Data Olahan)

\subsection{Pembahasan}

Prosedur penyusunan anggaran pada Badan Perencanaan Penelitian dan Pengembangan Daerah Kota Manado dimulai dengan rapat koordinasi dari masing-masing kepala bidang untuk menentukan program dan kegiatan dalam rangka menyusun rencana kerja yang akan dilaksanakan, kemudian penyusunan dan penetapan kebijakan umum anggaran, prioritas plafon anggaran sementara, rencana kerja anggaran, penyusunan dan penetapan peraturan daerah tentang anggaran pendapatan dan belanja daerah sampai penyusunan dokumen pelaksanaan anggaran. Dalam pelaksanaan anggaran pendapatan dan 
belanja daerah, wewenang dan tanggung jawab diberikan kepada Walikota, serta dibahas dan disetujui bersama dengan Dewan Perwakilan Rakyat Daerah Kota Manado. Setelah melihat prosedur penyusunan anggaran, kemudian dalam penerapannya dilihat dari Peraturan Pemerintah Nomor 12 Tahun 2019 tentang Pengelolaan Keuangan Daerah, setiap tahapan yang ada sudah sesuai sebagaimana tahapan-tahapan yang ada sudah dilaksanakan.

Faktor-faktor yang menjadi bahan pertimbangan dalam penyusunan anggaran belanja Badan Perencanaan Penelitian dan Pengembangan Daerah Kota Manado adalah kegiatan harus ada luaran yang jelas, efisiensi (kesesuaian harga), anggaran tahun sebelumnya. Hal itu merupakan salah satu tolok ukur yang mendorong agar realisasi anggaran akan sesuai dengan yang dianggarkan, walaupun seringkali pada kenyataannya akan sangat sulit untuk mendapatkan hasil yang sesuai dengan apa yang dianggarkan, untuk itu dibutuhkan tanggung jawab yang baik dalam setiap program dan kegiatan yang akan dilaksanakan.

Analisis selisih antara anggaran dengan realisasi berdasarkan analisis varians, selisih tahun 2016 sebesar Rp2.038.250.721,00 dan tingkat persentase ketercapaian belanja 86,79\%. Selisih tahun 2017 sebesar Rp2.400.948.640,00 dan tingkat persentase ketercapaian belanja 84,12\%. Selisih tahun 2018 sebesar Rp1.760.466.955,00 dan tingkat persentase ketercapaian belanja 90,88\%. Dilihat dari semua perubahan anggaran tahun 2016 sampai tahun 2018 dalam penyerapannya sudah baik, sehingga selisih yang ada pada badan perencanaan penelitian dan pengembangan daerah kota Manado tidak melebihi dari yang dianggarkan, kalaupun melebihi semua harus melalui mekanisme revisi anggaran. Melihat dari selisih yang terjadi dengan menggunakan analisis varians menunjukkan selisih yang cukup signifikan dari anggaran, selisih tersebut disebabkan karena Badan Perencanaan Penelitian dan Pengembangan Daerah Kota Manado melakukan penghematan anggaran dalam setiap kegiatan. Meskipun dilihat dari sisi kinerja keuangan kurang dan tidak mencapai $100 \%$, tetapi jika dengan hasil tersebut luarannya sudah tercapai maka itu merupakan hal yang baik, sebaliknya dari sisi keuangan sudah mencapai $100 \%$ tetapi luarannya tidak tercapai, itu merupakan hal yang tidak baik. Akan tetapi, Badan Perencanaan Penelitian dan Pengembangan Daerah Kota Manado telah melaksanakan tanggung jawab yang baik dalam pengelolaan keuangan, karena telah melakukan penghematan pada anggaran dan setiap luarannya boleh tercapai. Oleh sebab itu, pentingnya perencanaan biaya atau anggaran untuk pengendalian anggaran, agar tidak terjadi realisasi yang tidak sesuai dengan yang dianggarkan.

\section{KESIMPULAN DAN SARAN}

\subsection{Kesimpulan}

Berdasarkan hasil penelitian dan pembahasan maka dapat ditarik kesimpulan berikut:

1. Prosedur penyusunan anggaran belanja Badan Perencanaan Penelitian dan Pengembangan Daerah Kota Manado melalui beberapa proses atau tahapan yaitu: penyusunan rencana kerja, penyusunan rancangan Kebijakan Umum Anggaran (KUA) dan Prioritas Plafon Anggaran Sementara (PPAS) sampai kepada penetapannya oleh Walikota dan Dewan Perwakilan Rakyat Daerah (DPRD) Kota Manado, penyusunan dan penyampaian Surat Edaran (SE) tentang pedoman penyusunan Rencana Kerja Anggaran (RKA), pembahasan Rencana Kerja Anggaran (RKA) oleh Tim Anggaran Pemerintah Daerah (TAPD), penyusunan dan penetapan rancangan peraturan daerah tentang Anggaran Pendapatan dan Belanja Daerah (APBD) dan penjabaran Anggaran Pendapatan dan Belanja Daerah (APBD), dan penyusunan Dokumen Pelaksanaan Anggaran (DPA).

2. Pada saat menyusun anggaran belanja ada faktor-faktor yang menjadi pertimbangan dalam penyusunan anggaran. Faktor-faktor pertimbangan tersebut yaitu: kegiatan harus ada luaran yang jelas, efisiensi (kesesuaian harga), dan anggaran tahun sebelumnya. 
3. Hasil dari analisis varians yang dilakukan pada anggaran belanja Badan Perencanaan Penelitian dan Pengembangan Daerah Kota Manado, secara keseluruhan selisih yang terjadi masih menguntungkan, karena realisasi masih lebih rendah dari yang dianggarkan. Penyebab terjadinya selisih dikarenakan ada penghematan pada beberapa kegiatan, dengan selisih tahun 2016 sebesar Rp. 2.038.250.721,00 dan tingkat persentase ketercapaian belanja 86,79\%. Selisih tahun 2017 sebesar Rp. 2.400.948.640,00 dan tingkat persentase ketercapaian belanja 84,12\%. Selisih tahun 2018 sebesar Rp. 1.760.466.955,00 dan tingkat persentase ketercapaian belanja 90,88\%.

\subsection{Saran}

1. Dalam penyusunan anggaran pada Badan Perencanaan Penelitian dan Pengembangan Daerah Kota Manado harus tetap dipertahankan karena sudah sesuai dengan pedoman. Lebih memperhatikan faktor-faktor yang menjadi pertimbangan agar anggaran digunakan sesuai dengan yang direncanakan, sehingga penyerapan anggaran berjalan dengan baik.

2. Badan Perencanaan Penelitian dan Pengembangan Daerah Kota Manado dapat melakukan usaha untuk mengurangi atau menghilangkan selisih yang terjadi pada program-program anggaran belanja. Usaha tersebut dapat dilakukan dengan menetapkan angka anggaran yang lebih memperhatikan standar harga pasar dan memperhatikan program yang perlu dilaksanakan.

\section{DAFTAR PUSTAKA}

Giri, E. F. (2017). Akuntansi keuangan menengah 1, Edisi kedua. Yogyakarta: UPP STIM YKPN.

Kainde, C. (2013). Analisis varians dan pertumbuhan belanja daerah pada Pemerintah Kota Bitung. Jurnal EMBA: Jurnal Riset Ekonomi, Manajemen, Bisnis dan Akuntansi, 1(3), 393-400. https://ejournal.unsrat.ac.id/index.php/emba/article/view/1838

Liando, G. Y., \& Elim, I. (2016). Analisis kinerja belanja dalam Laporan Realisasi Anggaran (LRA) pada Dinas Pendapatan Pengelolaan Keuangan dan Asset Daerah Kabupaten Kepulauan Sangihe. Jurnal EMBA: Jurnal Riset Ekonomi, Manajemen, Bisnis dan Akuntansi, $4(1)$,

1473-1484. https://ejournal.unsrat.ac.id/index.php/emba/article/view/12369

Mahmudi. (2016). Analisis laporan keuangan pemerintah daerah. Edisi ketiga.Yogyakarta: UPP STIM YKPN.

Mahsun, M. (2013). Pengukuran kinerja sektor publik. Yogyakarta: BPFE.

Mardiasmo. (2018). Akuntansi sektor publik, Edisi terbaru. Yogyakarta: Andi.

Nuru, F., Saerang, D., \& Morasa, J. (2013). Pengaruh pengetahuan anggaran, partisipasi masyarakat dan transparansi kebijakan publik terhadap fungsi dewan dalam pengawasan Anggaran Pendapatan Dan Belanja Daerah (APBD). Jurnal Accountability, 2(1), 140-150. https://doi.org/10.32400/ja.2351.2.1.2013.140-150

Puranta, H. B., \& Yunita, A. (2010). Anggaran berbasis kinerja: Penyusunan APBD secara komprehensif. Yogyakarta: UPP STIM YKPN.

Peraturan Pemerintah Peraturan Pemerintah Republik Indonesia Nomor 58 Tahun 2005 tentang pengelolaan keuangan daerah.

Peraturan Menteri Dalam Negeri Nomor 21 Tahun 2011 tentang pedoman pengelolaan keuangan daerah.

Peraturan Pemerintah Republik Indonesia Nomor 71 Tahun 2010 tentang standar akuntansi pemerintahan. 
Peraturan Pemerintah Republik Indonesia Nomor 12 Tahun 2019 tentang pengelolaan keuangan daerah.

Siregar, B. (2017). Akuntansi sektor publik (akuntansi keuangan pemerintah daerah berbasis akrual), Edisi kedua. Yogyakarta: UPP STIM YKPN.

Sujarweni, V. W. (2015). Akuntansi sektor publik. Yogyakarta: Pustaka Baru Press.

Tantri, S., \& Irmawati, P. (2018). Analisis kinerja anggaran belanja pada dinas kebudayaan daerah istimewa Yogyakarta tahun 2012-2016. Jurnal Akuntansi Terapan Indonesia. 1(1), 27-37. http://journal.umy.ac.id/index.php/jati/article/view/3815 